\title{
THE IMPLEMENTATION OF CRIMINAL SANCTIONS IN THE CRIMINAL CODE AGAINST CRIMINAL ACTION BASED ON THE VALUE OF JUSTICE
}

\author{
Hanuring ayu ardhani putri \\ Lecturer at Batik Islamic University Surakarta \\ hanuringayu000@gmail.com
}

\begin{abstract}
The right to life is a human right listed in the Constitution of the State referred to in Article 28 (a) of the 1945 Constitution of the State of the Republic of Indonesia. Abortion is frequent in village. Health experts have not given a definite response, they vaguely see the agreement that abortion can be done by considering the cause, the future of the child and the psychological reason of the family, especially the mother, provided it is done in a way that meets certain conditions. The social experts also have the same idea as the health experts. This study aims to analyze the women's rights from the perspective of human rights and the application of criminal sanctions for perpetrators of criminal acts of abortion. The research method usesd was normative juridical, where both research data were obtained from references of literature and applicable legislation, and then the data were analyzed from court decision. It was concluded that the application of criminal sanction by Judge to perpetrator of abortion crime in Indonesia is still very low compared to criminal punishment contained in the Criminal Code.
\end{abstract}

Keywords: criminal sanctions, perpetrators of crime, abortion, justice.

\section{A. Introduction}

The right to life is one of the human rights mentioned in the Constitution of the State referred to in Article 28 (a) of the 1945 Constitution of the State of the Republic of Indonesia which reads "Everyone has the right to live and have the right to survive and life". With the right to life the state must protect the right to life of every, so that the state through law enforcement will act if there is violation of human right. ${ }^{1}$

Abortion is one of the topics that is always interesting to talk about. Religious experts, health experts, lawyers and socio-economic experts respectively have an opinion on abortion. The opinions expressed by these scholars are contradictory, abstentional, and some even support abortion. Abortion has always been the talk of both official and unofficial forums regarding medicine, law and other disciplines. ${ }^{2}$ Abortion is not a new issue, abortion is an old problem that is always reaping controversy.

1 Masrudi Muchtar, 2014, Midwife and Dynamics of Reproductive Health Law in Indonesia, Yogyakarta, Aswaja, p. 81

2 Achadiat Charisdiono, 2007, Dynamics of Ethics and Medical Law, Book of Medicine, Jakarta, p. 12
The phenomenon of abortion itself is now quite worrying in various circles. The number of abortion cases should be the concern of many parties. From various sources mentioned that the age of abortion are done by adolescents who are still in school. In one hand, abortion for non-medical reasons is strictly prohibited in Indonesia, but on the other hand illegal abortion increases the risk of death due to lack of medical facilities and infrastructure, even illegal. Abortion is mostly done in a traditional way which further increases the risk of death.

Health experts have not given a definite response, they vaguely see the agreement that abortion can be done by considering the cause, the future of the child and the psychological reason of the family, especially the mother, provided it is done in a way that meets certain conditions and conditions. The social experts also have the same idea as the health experts.

In Indonesia, according to the Association of Obstetrics-Gynecology Indonesia (2004) there were 3 million unwanted pregnancies and $60 \%$ of whom ask for an abortion. The problem is in addition to the possibility of couples who do 
not use anti-pregnancy pills or condoms, they have a sex before marriage. Moreover, they forget the safety device because their minds are dominated by their desire.

According to data from the Indonesian Demographic and Health Survey (IDHS) in 2008, the national average maternal mortality rate reached 228 per 100,000 live births. From this number, abortion deaths accounted for 30 percent. Meanwhile, the 2013 report from the Australian Consortium for In Country Indonesian Studies showed the results of research in 10 major cities and 6 districts in Indonesia occurred 43 percent of abortions per 100 live births. Abortion is done by women in urban areas by $78 \%$ and rural women by $40 \%$. The survey results of the Central Bureau of Statistics in 2012 revealed that the number of teenage pregnancies at the age of $15-19$ years reached 48 out of 1,000 pregnancies.

Many women get pregnant out of wedlock and have an abortion as a sign of moral degradation. Unwanted pregnancy is not a reason to kill the fetus. The fetus is the creature of Allah SWT. Why it should be killed? The wrong site is the adulterers or rape not the fetus. The fetus also has the right to live. Legalizing abortion is not a solution to suppress maternal mortality. This amount will increase because there is the possibility of fetus owners claimed to be raped for having an abortion. ${ }^{3}$

As it is known, the setting of criminal abortion crimes in the Criminal Code is contained in Chapter XIV Book II of the Criminal Code on Crimes Against Life, in Article 299, Article 346, Article 347, Article 348, 349. To facilitate this Study, it is especially directed at sanctions against perpetrators abortion. This research also look at the rights of women from the perspective of human rights. In addition to the criminal sanctions imposed by judges on abortion perpetrators in Indonesia has not been based on the value of justice.

This study is normative Juridical, it check the effectiveness of a Law and Research which want to know the correlation between the various symptoms or variables as a means of data

3 Adang Hawari, 2005, Forbidden Love, BP. FKUI, Jakarta, p. 56 collection which consists of document studies. The main legal material is binding legal material and consists of: Norms or basic rules, namely the Preamble of the Constitution of the Republic of Indonesia Year 1945. - Basic Regulations, namely the body of the 1945 Constitution and the MPR (House of Representative). Immaculate Legislation legal material, such as the Law of Jurisprudence. As well as secondary legal materials in the form of draft laws, research results or opinion of legal experts in the form of academic theoretical activities that compensate for legislative practice (or judicial practice as well). And tertiary legal materials from draft laws, legal dictionaries, and encyclopedias.

\section{B. Discussion}

\section{Women's Rights Reviewed from Human} Rights Perspective

From a human rights perspective, a woman has the right to get an abortion service because it is part of a very basic reproductive health right. In Law no. 36 of 2009 on Health Article 72 also contains provisions on guarantees of each person to perform reproduction. But in this case Abortion is an unavoidable condition for women who do not want their pregnancy for some reason.

Reproduction is the function of living things to degrade human next generation, naturally equipped with biologically organs. Likewise humans, the determination of reproductive behavior derives from its own hormones and also the presence of reproductive organs, which are between females and males, it enable them to have sexual intercourse. Biologically, the way hormones interact with sexual behavior in humans is no different with animals. What distinguishes is that humans can control themselves with their minds.

Reproductive health is a state of complete physical, mental, and social health, not solely free from diseases or disabilities associated with the reproductive system-functions and processes in men and women. ${ }^{4}$ Therefore, reproductive health means people can have a satisfying and secure sex life, and they have the ability to reproduce and the freedom to decide what they

4 Health Act Number 36 Year 2009 
want, when and how. In the latter case including, the right of men and women to obtain information and access to safe, effective, affordable and acceptable family planning methods as their choice. Further, they can also use other noninfringing methods, and the right to get appropriate health care services which allows women to conceive and give birth to children safely, as well as the opportunity to have a healthy baby. ${ }^{5}$ Talking about reproductive health, it cannot be separated from issues of reproductive rights, sexual health, and sexual rights.

The right to reproduction is a part of human rights that includes the right of each spouse and the individual to decide freely and responsibly the number, distance, and time of birth of the child, and has information and means to do so. Sexual health is a state to achieve reproductive health that requires a person's sex life to be satisfactorily and healthy in the sense of being free from disease and other disorders. Related to this, the sexual right is a part of human rights to decide freely and responsibly to all matters relating to sexuality, including sexual and reproductive health, freedom from coercion, discrimination and violence.

Basic principles of sexual and reproductive rights: ${ }^{6}$

1. The integrity of the body, the right of the body itself, is not only free from torture and physical evil, as well as to enjoy the potential of their bodies for the health, birth and enjoyment of safe sex,

2. Personality, refers to the right of women to be treated as actors and decision makers in sexual and reproductive matters and as subjects in related policies.

3. Equality, equality of rights between men and women, not only in terms of stopping gender, race and class discrimination, but also ensuring social justice and conditions that benefit women, such as access to reproductive health services.

4. Diversity, appreciation of the values, needs, and priorities of women and women who

\footnotetext{
5 Titon Slamet Kurnia. Reparations Against Victims of Human Rights Abuses in Indonesia, PT. Citra Aditya Bakti, Bandung p. 45

6 Ibid., p. 56
}

are self-defined in accordance with their existence as individuals and members of a particular society.

The problem raises when pregnancy really threatens the life of the mother. In this case, abortion may be justified on the basis of legal defense. People have the right to defend themselves against other attacks that are clearly life-threatening, even if defending themselves then the agator is forced to kill. Since objectively there is no other way unless the assailant is killed. Here, it should be underlined that the aim is to defend, ie to preserve her life. In the case of a dangerous pregnancy, killing the fetus is not the purpose of his actions. The purpose of this act is to save the mother's life, and the fetal death is merely the effect of the action, which is objectively forced to happen.

Still on the same track, it can be said that in pregnancy that endangers the life of the mother, we are faced with competition between two equally valuable persons, but in but we have no choise. And the possibility of life can be determined by others who must be saved. In fact, if both can be saved, then both must be saved. However, if one has to choose, then a life that can be saved must take precedence over that which can not be saved.

Therefore, if medical indications explain that pregnancy will kill the mother and the child, then saving her mother is right justified morally, since the mother also has the right to survive. Similarly, if continuing the pregnancy meant her mother's death and the termination of pregnancy (abortion) could save her mother, then saving the mother would have been morally justified.

People often justify abortion, arguing that abortion is a woman's personal autonomy exercise to regulate her own body, self-determining what is good and bad for her body. However, according to this argument, there are many weaknesses based on the following principle;

First, it is true that everyone has the right to govern their bodies according to what the owner of the body sees. Even a doctor is not entitled to conduct medical intervention in the patient's body without permission from the owner of the body. However, it must be remembered that the fetus is not part of the female body, therefore 
the mother has no right to organize it. It is true that the egg comes out of its body, and as long as it has not come out of its ovaries, it is part of its body. However, once the egg is fertilized, it becomes another entity altogether, and not part of its mother.

As we saw in the previous chapter, since the conception, the fetus already has another genetic code. She is completely different from her father and her mother. The mixing of the chromosomes of her mother and father, who both donated half to their child, turned out to form a unique human being, which is second to none. This is the uniqueness of blood type, bone structure, face, personality and so on.

If the fetus is really part of her mother, then it must be said that the mother has 4 legs, 4 letters, 2 faces, and if the male is male then she has double genitals, male and female. Is that true? Artificial fertilization programs, especially surrogate mothers, will further underscore this separation. If a white-skinned egg is fertilized by white sperm, although after fertilization is inserted into the womb of a black person, the baby will still be born white. Genetically, the black mother does not affect the baby, even though her baby is nine months in the womb, and consumes the nutrients the black mother consumes. So, after all, once the egg is fertilized, it will be a different entity from his mother. She is not part of her mother any more, therefore she has no right to organize it when she organizes her own body.

Second, the right to govern her own body certainly applies to everyone. Who deserves not only the mother, but everyone, both pregnant and non-pregnant. The exercise of that right can be justified to the extent that it does not interfere with the exercise of the rights of others. In other words, the exercise of that right can never be justified if its implementation interferes with the exercise of the rights of others. This is even more justified for those who are harassed is the basic right of every human being, the right to life.

Third, it is not comparable. It must be admitted that the presence of a fetus in the womb for a mother who does not want her baby can be a mental burden and cause suffering for the mother. However, the suffering of the mother cannot be sufficient reason for revenge, even causing even greater suffering, the fetus itself, especially if the answer to the baby's life is lost. Of course this is injustice. Furthermore, if revenge is directed to the weak and helpless, then it is clearly unjustifiable. Here, the prevailing principle is the prevailing law of vulnerability, that the strong must protect the weak.

Abortion is closely related to human rights, on the one hand it is said that every woman has the right to her body and she is entitled to live reproductive life and live healthy, safely, and free from coercion. However, on the one hand, again the fetus in the womb is also entitled to continue to live and grow. Both are contradictory because they involve two lives. If abortion is a very important abortion, of course it is very contrary to human rights.

The Human Rights Act also regulates the protection of children from the fetus because even if a mother has the right to her own body, we must keep in mind that everyone's basic rights are still restricted by law. But when a mother has to abort her pregnancy with an indication that a medical emergency is detected to threaten the mother or fetus's life, human rights can be justified because the mother also has the right to live and sustain her life.

\section{Implementation of Criminal Law for Abortion in the Criminal Code}

The formal elements of a crime include:

a. Human action, namely deed in a broad sense, means not doing the human actions

b. Violate criminal regulations. in the sense that something will be punished if there is a previous criminal act that regulates the action, so the judge cannot accuse crimes committed with a criminal code, so there is no crime

c. Threatened punishment, this means that the Criminal Code provides a different penalty based on the crime committed.

d. Conducted by the guilty person, where the elements of error must be the will of the person committing the crime 
and the person doing something intentionally, know and aware of the consequences of his/her actions first. Errors in the narrow sense can be interpreted as an error caused by the lack of attention of the author to the consequences of the unwanted by law.

e. Accountability that determines that unhealthy people's memories cannot be accounted for. The basis of one's responsibility lies in the state of his soul.

The material elements of the crime are contrary to the law, which must be genuinely felt by society, so that such action is not feasible. Hence, even if the action meets the formulation of the law, but if it does not violate the law, then the action is not a crime. The elements of criminal acts in criminal law are distinguished in two types, namely objective and subjective elements. The objective element is the element that exists outside the performer. These elements are among others.

a. A deed or human behavior, where action of human being (doing something), such as killing (Article 338 KUHP), torture (Article 351 Criminal Code).

b. The consequence is the absolute requirement of the offense. This is contained in consideration of material or material deliberations, such as murder (Article 338 of the Criminal Code), persecution (Article 351 of the Criminal Code), and others.

c. There are elements that are against the law. Any act that is prohibited and punished by criminal law by such criminal law should be against the law, although this element is not expressly stated in its formulation. Criminal acts also recognize the existence of a subjective element, this element includes.

a. Deliberation (dolus), which is contained in a moral violation (Article 281 of the Criminal Code), deprivation of liberty (Article 333 of the Criminal Code), murder (Article 338).

b. Negligence (culpa), which is contained in the deprivation of liberty (Article 334 of the Criminal Code), and causes death (Article 359 of the Criminal Code), and others.

c. Intention (voornemen), which is contained in the experiment or poging (Article 53 of the Criminal Code).

d. The goal (oogmerk), where it is contained in the theft (Article 362 of the Criminal Code), extortion (Article 368 of the Criminal Code), fraud (Article 378 of the Criminal Code), and others.

e. With the previous plan (met voorbedachte rade), who was present in the disposal of his own son (Article 308 of the Criminal Code), killed his own son (Article $341 \mathrm{KUHP}$ ), killed his own son by plan (Article 342 of the Criminal Code)

\section{Conclusions}

The application of criminal sanction by Judge to perpetrator of abortion crime in Indonesia is still very low compared to criminal punishment contained in Criminal Code which is threatened only 4 years imprisonment or fine not more than three thousand rupiah (Article 299 KUHP), maximum of four years imprisonment (Article $346 \mathrm{KUHP}$ ), a maximum of twelve years in prison (Article 347 of the Criminal Code), and a maximum imprisonment of five years and six months (Article 348 of the Criminal Code). In Indonesia Judges have the freedom to impose criminal sanctions because in Indonesian Criminal Code is known as minimum system of general pattern that is 1 (one) day and maximum for each particular crime.

The criminal sanctions imposed by judges on abortion perpetrators in Indonesia have not been based on the value of justice, because they are imposed irrespective of the background of the criminal act of abortion and the person committing the criminal act of abortion. The second is the and perpetrators. This is stated in 
Articles 346, 347, 348, and 349 of the Criminal Code. Because the judge has not considered the value contained in the Article and has not considered local wisdom and international wisdom. The value of local wisdom includes the value of justice, equilibrium value, and the value of protection.

\section{BIBLIOGRAPHY}

Achadiat Charisdiono, 2007, Dinamika Etika dan Hukum Kedokteran, Buku Kedokteran, Jakarta,

CB. Kusmaryanto, SCJ, 2002. Aborsi Kotoversi, Gramedia Widiasarana Indonesia, Jakarta. Dadang Hawari, 2005, Forbidden Love, BP. FKUI, Jakarta.

Masrudi Muchtar, 2014, Bidan dan Dinamika Hukum Kesehatan Reproduksi di Indonesia, Yogyakarta, Aswaja

Titon Slamet Kurnia, Reparasi Terhadap Korban Pelanggaran HAM di Indonesia, PT. Citra Aditya Bakti, Bandung

Undang-Undang Nomor 36 Tahun 2009 tentang Kesehatan.

http://www.cnnindonesia.com/nasional/20141029111311-12-8642/tercatat-angka-aborsimeningkat-di-perkotaan 